\title{
The Influence of the Use of Accounting Information and Information Technology on the Success of Business Performance (A Survey on Micro, Small and Medium Enterprises (MSMEs) of Superior Products in Banyumas Regency)
}

\section{H. Fathul Aminudin Aziz and Hastin Tri Utami}

Faculty of Islamic Economics and Bussines IAIN Purwokerto

\section{Abstract}

Financial This study aims to determine the influence of the use of accounting information and the use of information technology on the success of business performance in superior $\mathrm{p}$ roducts of micro, small and medium enterprises (MSMEs) in Banyumas Regency. The population in this study are MSMEs business leaders who are included

Received: 10 February 2019

Accepted: 14 March 2019

Published: 28 March 2019

Publishing services provided by Knowledge E

(c) H. Fathul Aminudin Aziz and Hastin Tri Utami. This article is distributed under the terms of the Creative Commons

Attribution License, which permits unrestricted use and redistribution provided that the original author and source are credited.

Selection and Peer-review under the responsibility of the ICIEBP Conference Committee. in the list of superior products in Banyumas Regency. The sample using purposive sampling method. The number of respondents in this study were 38 MSMEs business leaders. Hypothesis testing uses multiple linear regression method. Based on the results of the analysis using the SPSS version 25 application shows the results that the use of accounting information (X1) has a positive effect on the success of business performance and the use of information technology $(X 2)$ has a positive effect on the success of business performance. In addition, the results of the study also show that the level of use of accounting information and the use of information technology in MSMEs business leaders for superior products in Banyumas Regency has not been maximized. The limitations of this study include 1) the factors analyzed are limited only on the internal company factors which include the use of accounting information and the use of information technology, 2) this study more focuses on the answers of questionnaires from respondents, further research can focus more on in-depth interviews with respondents.

Keywords: Use of Accounting Information, Use of Information Technology, Success of Business Performance, MSMEs

\section{Research Background}


than 57,900,000 units, while in 2017 the number of MSMEs was more than 59,000,000 units. Means there has been an increase in the number of MSMEs reaching 1,100,000 units for one year (Department of Cooperatives and Small-Medium Enterprises, 2017). The number of business leaders in Small and Medium Enterprises in Banyumas also shows an encouraging number. The number of business leaders in Small and Medium Enterprises as of March 31, 2013 shows a fairly high number of 581,049 business units. This development is quite significant considering the number of SMEs in Banyumas Regency in 2010 was 578,564 business units (Department of Industry, Trade and Cooperatives (Dinperindagkop) Banyumas, 2013). The progress of information technology and the development of internet is not only causing the changing in establishing social relations, but also changing consumption patterns and spending activity. The digital economy is open to anyone and opens opportunities for Micro, Small and Medium Enterprises (MSMEs) to participate in competition so that it is expected to create a lot of new business fileds.

Lucas (2000) states that information technology is all form of technology that applied to process and send the information in electronic form. Information technology is a term in an accounting information system that presents an information for users. Accounting Information systems are a human resources and capital to prepare the financial information and information obtained from collection activity and processing of transaction (Baridwan 2003: 3). According to Diana (2011: 4)definition of accounting information system is a system which aims to collect and process the data and also report the information which is retaled to financial transaction. Processing the transaction means that recording the activity of cash disbursement into the journal entry.

In general, the purpose of utilizing information systems and information technology in MSMEs more emphasis on reducing the number of errors in processing transactions that have been carried out manually and providing accurate and timely financial statement information that can be used by management to make business performance decisions. According to Indarjanti and Bodroastuti (2012), performance is a description of the level of achievement's implementation of an activity program or policy in realizing the goals, objectives, vision and mission of the organization as outlined through the strategic planning of an organization. The measurement of company performance aims to determine the extent to which the company's development has been achieved. Knowledge of the conditions that occur now is the basis of the company to make improvements and take steps to be taken in the next stage. Performance measurement system designed by Robert S. Kaplan and David P. Norton in Ferdinandus Agung Himawan and Juansah, performance measurement includes four perspectives, namely 
financial perspective, customer or consumer perspectives, internal business processes and learning and growth perspectives.

Al-shaikh (1998) found that the biggest causes of failure in SMEs were poor planning (20.5\%), poor management (13.5\%), lack of financing (16\%), poor manager experience (8\%) and the biggest factor causing business failure in SMEs is poor quality of recording, lack of technology absorption and high taxes (24.5\%). Given that the biggest factor that caused the failure of SMEs was poor of recording and poor of technology absorption, it was very interesting to conduct research to identify how much influence the use of accounting information and the use of information technology toward on the success of business performance in Micro, Small and Medium Enterprises.

\section{Research Methods}

This research is a survey research. The research object in this study is the level of accounting information's uses, the use of information technology and the success of business performance in superior product SMEs in Banyumas Regency. The population in this study were the business leaders of superior MSMEs products in Banyumas. Sampling uses Purposive Sampling Method. Based on data obtained from the Department of Industry, Trade and Cooperatives (DINPERINDAGKOP) in Banyumas Regency in 2016 the number of SMEs which were superior products in Banyumas was 321 businesses, but those who met the criteria were 70 businesses. The data used in this study is primary data. Primary data is data obtained by researchers directly through questionnaires and interviews with respondents. The dependent variable in this study is business performance. The indicators of the success of business performance used in this study use indicators adopted from the research of Pratiwi (2008). The indicators used are: a) Increase in business volume, b) Increase in company profits, c) Increase in the number of workers. While the independent variable in this study is the use of accounting information and the use of information technology. Measurements used using a Likert scale where the answers dropped dramatically were given a score of 1 , down were given a score of 2 , stable agreed to be given a score of 3 , increased given a score of 4 , increased dramatically given a score of 5 .

Analysis of the data used in this study are:

1. Validity test, this test aims to examine whether each item of question in the questionnaire can really reveal the variable under study. Testing the validity in this study using the product moment correlation method. The validity criteria are: $r$ count $>r$ table $=$ valid, $r$ count $<r$ table $=$ invalid. 
2. Reliability test is a test for stability of a measurement tool in measuring an answer from the respondent. Reliability test was carried out by Cronbach Alpha test. Questions that have more than 0.6 Cronbach Alpha are declared to be reliable instruments (Suliyanto, 2005).

3. Classic assumption test, this test consists of:

(a) Normality test, aims to determine whether the data is normally distributed or not. To test whether the data is normally distributed or not, the Kolmogorov Smirnov test is used. If the significance value $>(\alpha) 0.05$ then the data is normally distributed.

Multicollinearity test is conducted to find out whether there is a very strong correlation between the independent variables. To find out the symptoms of multicollinearity between independent variables, one of them is by looking at the VIF value of each independent variable on the dependent variable. If the VIF value is less

(b) than 10 and the toll value is $>0.10$ then the model is declared not to contain multicollinearity.

(c) Heteroscedasticity test, the heteroscedasticity symptom will appear if the error or residual of the observed model does not have a constant variance from an observation to another observation. To detect it in a regression model can be done by the glejser test. If the probability value $>\alpha(0.05)$ then the model does not contain elements of heteroscedasticity (Suliyanto, 2005). d) Goodness Of Fit Test, the F test is conducted to examine the accuracy of the model (goodness of fit). Done by looking at the magnitude of Fcount. If Fcount $>$ Ftable then the model is declared to be fit.

4. Hypotheses Testing, testing Hypotheses 1 and 2 are using multiple regression analysis. It is a technique carried out to test the effect of independent variables on the dependent variable (Ghozali, 2009). The formula for multiple regression analysis is: $y=\alpha+\beta 1 \times 1+\beta 2 \times 2+e$ (where $y$ : Success of business performance, $\alpha$ : Constants, $\beta 1$ : Regression coefficients of using accounting information, $\beta 2$ : Regression coefficient of use of information technology, X1: Use of accounting information and X2: Use of Information Technology).

The test is conducted to test hypotheses 1 and 2 . Where this test is conducted to examine the effect of using accountin information and the use of information technology on the success of business performance. If tcount $<\mathrm{t}$ table or sig. $\leq \alpha(0.05)$ and the direction of the coefficient is positive, the hypothesis is accepted. 


\section{Results and Discussion}

\subsection{General overview of population, sample and respondent}

Data that meets the criteria as a sample is 70 businesses. From the 70 samples that were willing to become respondents and complete the questionnaire as many as 38 businesses so the questionnaire response rate was $52.7 \%$. Respondent data from each criterion are as follows: 


\begin{tabular}{|c|l|l|l|}
\hline \multicolumn{4}{|l|}{ Table l. Product Produced } \\
\hline No & Description & Amount & $\%$ \\
\hline 1 & Furniture & 3 & $8 \%$ \\
\hline 2 & Kecan (Soy Sauce) & 4 & $11 \%$ \\
\hline 3 & Getul & 5 & $13 \%$ \\
\hline 4 & Karoser (car body) & 4 & $11 \%$ \\
\hline 5 & Mino & 5 & $13 \%$ \\
\hline 6 & Keripil (Chips) & 3 & $8 \%$ \\
\hline 7 & $\begin{array}{l}\text { Gula Kelapa } \\
\text { (Coconut Sugar) }\end{array}$ & 2 & $5 \%$ \\
\hline 8 & Mie & 4 & $11 \%$ \\
\hline 9 & Sepatu bandol & 3 & $8 \%$ \\
\hline 10 & Sohun & 5 & $13 \%$ \\
\hline Tottal & 38 & $100 \%$ \\
\hline
\end{tabular}

Source: Processed data in 2018

\begin{tabular}{|c|c|c|c|}
\hline \multicolumn{4}{|c|}{ Table 2. Number of Employees Owned } \\
\hline No & Degeription & Amount & $\%$ \\
\hline 1 & 5 to 10 & 8 & $21 \%$ \\
\hline 2 & 10 to 15 & 12 & $32 \%$ \\
\hline 3 & 15 to 20 & 12 & $32 \%$ \\
\hline 4 & $>20$ & 6 & $16 \%$ \\
\hline & Tothal & 38 & $100 \%$ \\
\hline
\end{tabular}

Source: Processed data in 704 L

Table 3. Bugines Life

\begin{tabular}{|c|c|c|c|}
\hline No & Description & Amount & $\%$ \\
\hline 1 & 5 to 10 year & 5 & $13 \%$ \\
\hline 2 & 11 to $20 \mathrm{Jear}$ & 10 & $26 \%$ \\
\hline 3 & 21 to $30 \mathrm{Jear}$ & 14 & $37 \%$ \\
\hline 4 & 31 to $40 \mathrm{year}$ & 5 & $13 \mathrm{~h}$ \\
\hline 5 & $>40$ year & 4 & 118 \\
\hline & Tottal & 38 & $100 \%$ \\
\hline
\end{tabular}

Source: Processed data in $20 \mathrm{~h}$ 


\begin{tabular}{|l|l|l|l|}
\hline \multicolumn{4}{|l|}{ Table 4 . Business Scale } \\
\hline No & Description & Amount & $\%$ \\
\hline 1 & $\leq \mathrm{Rp} 2.500 .000,00$ & 0 & $0 \%$ \\
\hline 2 & $\mathrm{Rp} 2.600 .000-\mathrm{Rp} 5.000 .000,-$ & 2 & $5 \%$ \\
\hline 3 & $\mathrm{Rp} 5.100 .000,00-\operatorname{Rp~Rp~7.500.000,00~}$ & 6 & $16 \%$ \\
\hline 4 & $\mathrm{Rp} 7.600 .000,00-\operatorname{Rp} 10.000 .000,00$ & 5 & $13 \%$ \\
\hline 5 & $\geq \mathrm{Rp} 11.000 .000,00$ & 25 & $66 \%$ \\
\hline \multicolumn{2}{|c|}{ Tottal } & 38 & $100 \%$ \\
\hline
\end{tabular}

Source: Processed data in 2018

\begin{tabular}{|l|l|l|l|}
\hline \multicolumn{4}{|l|}{ Table 5 . Respondent based on Gender } \\
\hline No & Description & Amount & $\%$ \\
\hline 1 & Female & 20 & $53 \%$ \\
\hline 2 & Male & 18 & $47 \%$ \\
\hline Tottal & 38 & $100 \%$ \\
\hline
\end{tabular}

Source: Processed data in 2018

\subsection{Data analysis}

To test the validity and reliability of the questionnaire, it was firstly examine on 20 small business actors in Banyumas. Validity test is conducted using Product Moment Correlation assisted by SPSS Statistics version 25.00. It is known that the value of $r$ for product moment correlation for each question item for the variable business performance success and the use of accounting information each is greater than $r$ table at 0.320 at a $95 \%$ confidence level $(\alpha=0.05)$. Thus, all question items are declared valid. Reliability testing of the questionnaire in this study using Cronbach alpha. It is known that the cronbach alpha coefficient of success of business performance and the use of accounting information is 0.878 greater than 0.60 . Thus, all items in the questionnaire are declared reliable.

Based on the results of the normality test using SPSS 25.00, the Kolmogorov smirnov value was $0.867 ; 0,816 ; 0,867$ with asymp. Sig. ( 2 tailed) of 0.439 each; 0,840; 0.732 $>\alpha 0.05$, so it can be concluded that all data are normally distributed. A variable that declared have a multicollinearity if VIF is greater than 10. Furthermore, the results of the multicollinearity test show that the VIF value for each variable is 1.025 . So that it can be concluded that there are no symptoms of multicollinearity between the independent variables so that the independent variables used as predictors in this study are independent. Then, based on the results of heteroscedasticity test, the significance values for all variables were 0.037 and $0.016>0.05$, so that heteroscedasticity did not 
occur. Testing of Goodness of Fit, based on multiple linear regression output, obtained Fcount amounted to 19.877 greater than the value of $F$ table with $d f=(k-1)$ and $(n-k)$ amounted to 4.11. Thus, the regression model that formed is declared fit.

Table 6. Result of Multiple Regression Test

\begin{tabular}{|l|l|l|l|l|}
\hline No & Variable & Regression Coeff. & t count & sig \\
\hline 1 & Use of accounting information & 0.880 & 2.228 & 0.032 \\
\hline 2 & Use of Information Technology & 1.823 & 5.482 & 0.000 \\
\hline \multicolumn{4}{|l|}{ Constant $=11.867$} \\
\hline \multicolumn{4}{|l|}{ Adjusted R Square $=0.505$}
\end{tabular}

Source: Processed data using SPSS 25.0

Based on output of multiple linear regression analysis above we can make an regression equation as follow $Y=11.867+0,880 \times 1+1.823 \times 2+e$

Furthermore, test for examine Hypothesis 1 and 2 are as follow:

Testing Hypothesis 1: through multiple linear regression equations obtained regression coefficient value from the use of accounting information amounted to 0.880 positive or $>0$ and significance value $0.032<0.05$, it explains that the use of accounting information has a significant positive effect on the success of the superior product business performance in Banyumas. The results of data analysis using a 95\% confidence level $(\alpha=0.05$ ) obtained $t$ table of 2.0243. Based on the multiple linear regression output, the variable value of the use of accounting information is 2.228 greater than $t$ table, which is 2.0243 . Thus, the first hypothesis which states the higher use of accounting information will be the higher of success in the business performance of superior products MSMEs in Banyumas. So thus $(\mathrm{H} 1)$ is accepted.

Hypothesis Testing 2: through multiple linear regression equations obtained the regression coefficient of the use of information technology is 1,823 positive or $>0$ and a significance value of $0,000<0,05$, it explains that the use of information technology has a significant positive effect on the success of MSME's superior product performance in Banyumas. The results of data analysis using a 95\% confidence level $(\alpha=0.05)$ obtained $t$ table of 2.0243. Based on the multiple linear regression output, the value of variable for the information technology's use is 5.482, which is greater than t table 2.0243 . Thus, the first hypothesis which states the higher use of accounting information will be the higher of success in the business performance of superior products MSMEs in Banyumas. So thus $(\mathrm{H} 2)$ is accepted. 


\subsection{Discussion of the research results}

The results of testing the first hypothesis show that the use of accounting information has a positive and significant effect on the success of the business performance of superior products in MSMEs in Banyumas. This shows that when the use of accounting information is high, the success of the business performance of superior MSME products in Banyumas Regency is high and vice versa. So that it will impact to the increase in business volume, increase in company profits and increase in the number of workers. (Pratiwi, 2008).

The average respondent's answer regarding the use of accounting information is at 3.68, which means that the use of accounting information in superior product MSMEs in Banyumas Regency at a sufficient level and not maximally has led to the successful performance of MSMEs in superior products in Banyumas Regency and also not optimal. This can be proven by the respondent's answer regarding the success of business performance which has an average value of 3.63, which means that the success of business performance is at a stable level, this is due to the knowledge of business owners on the benefits of low accounting implementation. This is also confirmed based on the results of the answers in the questionnaire that only $38 \%$ of respondents had received training in accounting.

The results of this study support the research conducted by Utami (2016) where the use of accounting information is moderating the owner's knowledge variables and the success of business performance. The results of this study are also in accordance with Obrien (2005) that effective information will be useful for management. The use of an information system is expected to provide competitive advantage and comparative advantage for the company. In addition, the results of this study also reinforce the finding of Belkaoui (2003) which states that for management, accounting information has an important role in protecting company property, planning future corporate activities, measuring company income within a certain period of time, supervision company activities. Another reference is Hery (2013) which states that accounting information aims to determine whether a company is able to repay its debt in a timely manner to creditors (bankers, suppliers), so they need accounting information regarding the amount of cash available at the company before the maturity date loan / debt.

The results of testing the second hypothesis show that the use of technology has a positive and significant effect on the success of MSME's superior product business performance in Banyumas Regency. This shows that when the use of information technology is high, the success of the business performance of superior MSMEs products 
in Banyumas Regency is high and vice versa. This result is in line with the research conducted by Mutia Sari, et al (2017) where the use of information technology has a significant positive effect on managerial performance of financial management at the Regency Work Unit of Aceh Jaya regency government.

The average respondent's answer regarding the use of information technology is at the 0.55 , which means that on average the respondents answered that they have not used information technology in their business. The use of information technology that has not been maximized has led to the successful performance of MSME's superior products in Banyumas Regency, which have not been maximized. This can be proven by the respondent's answer regarding the success of business performance which has an average value of 3.63 , which means the success of business performance is at a fixed or stable level, due to the lack of socialization and training by the government regarding the use of information technology to support their business. This is also confirmed based on the results of the answers in the questionnaire that only $27 \%$ of respondents had received information on the utilization of information technology for MSMEs.

\section{Conclusions and Recommendations}

Based on the results of research and discussion that conducted in the previous chapter, so the conclusions can be drawn as follows: the use of accounting information has a positive and significant effect on the success of the business performance of superior product MSMEs in Banyumas Regency. Likewise, the use of technology has a positive and significant effect on the success of MSME's superior product business performance in Banyumas Regency.

According to in-depth interviews with respondents found the fact that the cause of the use of accounting information and the use of accounting information technology in superior product MSMEs in Banyumas district is still not optimal because most business owners have never received training in accounting or information technology. This needs to be a serious concern for the regional government and the central government, considering the use of accounting information and the use of information technology to be factors that influence the success of business performance. Currently to get loans from banks, for example, Micro, Small and Medium Enterprises (MSMEs) are required to have financial records. If not, the loan will have the risk of being rejected. In addition, it is currently the era of technology and social media so that Micro, Small and Medium Enterprises (MSMEs) are expected to be able to adopt information technology. The 
suggestions in this study are as follows. 1) This study only examines two independent variables, namely the use of accounting information systems and the use of information technology, it is expected that further research adds several variables that can improve business performance. For example, management support and skills possessed by individual technology users. 2) the research location centered on MSMEs in Banyumas regency, it is expected that the next research will be able to add the location of the study.

\section{References}

[1] Al-Shaikh, F. 1998. Factors for Small Bussiness Failure in Developing Countries. ACR Volume 2.

[2] Anastasia Diana, Lilis Setiowati (2011). Sistem Informasi Akuntansi, Perancangan, Proses dan Penerapan, Edisi I. Yogyakarta: ANDI

[3] Ang, J. and S. Koh. 1997. "Exploring the Relationships Between User Information Satisfaction". International Journal of Information Management 17(3), 169-177

[4] Baridwan, Zaki. 2003. Sistem Akuntansi Penyusunan Prosedur dan Metode. Edisi Kelima. Yogyakarta: BPFE

[5] Belkaoui. 2003. Accounting Theory, 5th edition. Singapore: Thomson Learning.

[6] Collin, S. M. H. and P. H. Collin. 1987. Dictionary of Information Technology. Teddington: Peter Collin Publishing.

[7] Disperindagkop. 2013. Data UKM di Kabupaten Banyumas Per triwulan Pertama. Banyumas.

[8] Depkop, 2017.

[9] Ghozali, Imam. 2009. Aplikasi Analisis Multivariate Dengan Program SPSS. Edisi 2. Badan Penerbit Universitas Diponegoro. Semarang.

[10] Heri. 2013. Cara Mudah Memahami Akuntansi. Prenada Media Group. Jakarta

[11] Indarjanti, Pratiwi dan Tri Bodroastuti. 2012. Pengaruh Kemampuan, Usaha, Dukungan Organisasi terhadap Kinerja. Sekolah Tinggi Ilmu Ekonomi Widya Manggala. http://jurnal.widyamanggala.ac.id/index.

[12] Lucas, H. 2000. Information Technology for Management (7 ${ }^{\text {th }}$, ed). Irwin/M.c Graw Hill

[13] Mutia Sari, dkk. 2017. Pengaruh Pemanfaatan Teknologi Informasi, Kompetensi Aparatur dan Komitmen Organisasi Terhadap Kinerja Manajerial Pengelolaan Keuangan Pada Satuan Kerja Peragkat Kabupaten Pemerintah Daerah Kabupaten Aceh Jaya. Jurnal Magister Akuntansi Universitas Syah Kuala: Banda Aceh 
[14] O'brien, James A. 2005. Introduction to Information System. Twelf Edition Mc Graw Hill, Northern Arizona.

[15] Pratiwi, Umi. 2008. Analisis Faktor-Faktor yang Mempengaruhi Persepsi Manajer Tentang Informasi Akuntansi Keuangan dan Pengaruhnya Terhadap Kinerja Perusahaan Kecil di Kabupaten Banyumas. Jurnal Akuntansi Manajemen dan Ekonomi, Volume 10.

[16] Suliyanto. 2005. Analisis Data Dalam Aplikasi Pemasaran. Bogor: Ghalia Indonesia.

[17] Utami, Hastin Tri. 2016. Pengaruh Pengetahuan Pemilik, Skala Usaha, dan Umur Usaha terhadap Keberhasilan Kinerja Usaha dengan Penggunaan Informasi Akuntansi Sebagai Variabel Moderasi. El Jizya: Purwokerto. 